\title{
Is The Sport Management Course Curriculum Compatible With Football Governing Institutions?
}

\author{
Akın Çelik \\ Correspondence: Akın Çelik, Faculty of Sports Science, Head of Sports Management, Trabzon University, Trabzon, \\ 61100, Turkey.
}

Received: March 6, 2019

Accepted: April 21, 2019

Online Published: April 24, 2019

doi:10.11114/jets.v7i6.4232

URL: https://doi.org/10.11114/jets.v7i6.4232

\begin{abstract}
Sport is becoming a global phenomenon. Moreover, it has been one of the major sources of income for the government in different countries. Therefore, sport management education is becoming increasingly important in the management of sports. Countries that spend more on the development of sports facilities have been associated with huge improvements in the sports industry. Similarly, clubs that spend more on acquiring new talents in the industry and availing sports facilities have been associated with higher performance. This led the European football clubs in the spending more than they earn so as to acquire the services of the best talents and avail the best sports facilities so as to perform better. Therefore UEFA (Union of European Football Associations) launched its financial fair play regulations. UEFA financial fair play regulations were introduced to prevent the European football clubs from overspending. This situation affects the education curriculum of the sports management departments in universities. The regulations have compelled the clubs to spend at the break-even point. This has led to the improvement in brand value, increased sponsors, and making decisions that do not lead the clubs to overspend. As a result, the clubs have grown economically and achieved higher financial stability. This research explores the adaptation of the sport management curriculum to these new situations.
\end{abstract}

Keywords: curriculum compliance, sports management students, sports management education, soccer economy, professional football

\section{Introduction}

Sport has already become a global phenomenon (Houlihan \& Malcolm, 2015). It has had a significant impact on the economies and social structures of the different countries in the world. It is an undeniable fact that sport is related to many different disciplines from social sciences to health sciences, natural sciences to educational sciences, behavioral sciences to management sciences (Alleyne et al, 2010; Caz \& Tunçkol, 2015; Özbay et al, 2018; Mumcu et al., 2017; Togo et al., 2018; Demir \& Akın, 2018; Özkara, et al., 2018; Toktaş \& Baş, 2019; Yılmaz, 2018 ). Therefore, countries that give importance to research on sports will be rewarded. Research shows that countries have hugely benefited from sports invested a relatively huge amount of capital in developing different sporting facilities. Examples of the countries which are currently deriving huge economic benefits from sport industry include England, Spain, the U.S., Brazil, France, Belgium, Russia, South Africa, Germany, and Italy (Kuper, 2014). Current research shows that the U.S. sports industry is more focused on Basketball and Rugby (Mathew, 2017). The other countries toping in the list of the top beneficiaries of sports activities mainly focus in Football. Football has had significant growth over the last century (Mellström, 2017). This growth has made it necessary professionalism in sports. The most important role in professionalization in sports belongs to sports professionals. Sports professionals are trained in the sports management departments of universities. This has increased more attention on the sporting industry by the governments of the different countries in the world so as to increase government revenue and get sufficient resources for financing the development activities and provision of public goods (Lewis \& Taylor, 2014). In order to achieve these goals in a productive and profitable manner, sport management education needs to keep up with this development. In Europe, specifically, in Germany, France, England, Italy, and Spain, football clubs have been necessitated to expand their capacity so as to accommodate the increasing number of fans (McLeod, 2016). The increasing number of fans has helped the clubs hire even more players and management professionals and offer relatively higher wages. Football players are amongst the highest paid employees in the European countries (Geurts, 2016). Previous researchers on the factors behind the rapid growth of the football clubs in Europe have been only describing the increased support from the government and the fans as the main reasons. Other factors that scholars have been citing include globalization which 
has made the interaction between people of different origins possible and the economic integrations of different countries such as the Commonwealth and European Union (Doidge, 2015). These unions promote immigration of laborers from one member country to another through reduced taxation rates. One of the major factors that have been ignored for long and its impact on the economic growth and stability of European clubs insufficiently discussed is the UEFA financial fair play (Appendini \& Bislev, 2016).

Before the introduction of the UEFA financial fair play, European football clubs were recording losses despite having professional players and individuals in managerial positions (Caglio, et al., 2016). This necessitated the clubs to borrow funds so as to meet their wage demands and address other activities. With these problems, the clubs would hardly afford the best talents in the industry; they would only depend on the academy graduates even for the major tournaments. Also, fans did not have trust in the events of the clubs. The only governing rules were developed by the Football Federations of the respective countries. The financial problems brought about by huge spending by the companies over the revenue necessitated the development of the UEFA financial fair play regulations which are a mandatory for all the clubs in Europe regardless of the tournaments which they participate (Frank, 2014).

UEFA financial fair play regulations were developed with the aim of preventing the professional football clubs in Europe from spending more than what they earn as they try to pursue success (Preuss, Haugen \& Schubert, 2014). The excess spending by the clubs brought them into problems that even went to the level of necessitating their insolvency. The fair play regulations were introduced to help prevent the clubs from indulging in the financial malpractices that would threaten their survival in the long-run (Sass, 2016).

UEFA financial fair play regulations were approved in the year 2010. The first assessment on the compliance to the regulations by the European clubs was done in the year 2011 (Fernandes, 2016). Since the year 2011, for a club to play in the UEFA competitions, it had to prove that it did not have overdue payable towards the players, tax or social authorities, and other clubs throughout the previous season. From the year 2013, the European clubs have also been subjected to break-even assessments. The clubs have been required to have a balanced spending pattern and avoid the accumulation of debts (Fernandes, 2016). Clubs that had not met the break-even requirement by the year 2014 were sanctioned in the financial year 2014/2015. This requirement has been a success in helping the European clubs achieve sustainable investment and maintain the control on overspending. Other areas that the fair play regulations have impacted include business restructuring of the clubs and response to the economic shocks (Nicoliello \& Zampatti, 2016).

Clubs that had not met the break-even requirement by the year 2014 were sanctioned in the financial year 2014/2015. This requirement has been a success in helping the European clubs achieve sustainable investment and maintain the control on overspending. Other areas that the fair play regulations have impacted include business restructuring of the clubs and response to the economic shocks (Nicoliello \& Zampatti, 2016).

European clubs that play in the UEFA competitions are not completely forbidden from incurring losses; they can borrow up to $€ 5$ million but per just a single period of assessment which covers a period of three years. Clubs which do not take part in UEFA competitions but they are planning to once take part are also subjected to the assessment. Since the year 2010 when the UEFA fair play regulations became effective, European clubs, especially those which take part in European competitions, have significantly achieved success in economic development and sustainability (Schubert, Könecke \& Pitthan, 2016). This paper sheds light on the different areas that have significantly benefited from the existence of the UEFA financial fair play regulations hence bringing about economic growth and stability of the European clubs.

\section{Method}

The different articles shedding light on the influence that the UEFA financial fair play regulations have had on the growth of the European clubs will be analyzed in this study. A document analysis which is a systematic procedure for reviewing or evaluating documents was performed as the method of data collection within the context of a descriptive approach (Bowen, 2009; Özkara, 2018).Conclusion will be based on the findings of the articles.

\subsection{Literature Review}

\section{Sport Management Education}

The purpose of sports management programs at universities is to respond to human resource need in various sports facilities and various areas, such as brand development, marketing, finance, field materials, public relations, and sports facilities management. Today, the management of professional sports, especially football, by individuals who have been trained in sports management has been inevitable. Sports management is one of the areas significantly affected by the existence of the UEFA fair play regulations. Sports managers in the field of sports play just the same role played by business managers; they determine the performance of the organization off and on the playing field (Galariotis, Germain, \& Zopounidis, 2018). In football, according to Gomes, at al., (2017), performance is mainly based on the quality of the players. For example, in the 2017/2018 season, Manchester City used as much as €213.8 million in 
buying quality players from the different clubs in Europe. This was a huge amount compared to that which the different clubs taking part in the English Premier League spent. The club was really outstanding in the season managing to beat Chelsea, the reigning champions, home and away and emerging as the winners at the end of the season. The same happened in France where PSG had to spend a lot of money to acquire the services of Neymar and Mbappe. This led them to the winning of the League 1 cup and beating Monaco, the reigning champions, home and away. This confirms the findings of the previous researchers on the determinants of the strengths of the European clubs that the more the clubs spend, the stronger they are. To achieve the best performance, the managers of the European clubs would spend more than the revenue so as to acquire the services of the best talents in the industry. This brought about huge debts that brought about poor economic growth and financial instability. Since the year 2010, clubs have been spending based on their earnings so as to avoid going against the UEFA fair play requirements. This has helped clubs maintain control of their expenditures and achieve huge growth by attracting more investors due to increased confidence and trust among the stakeholders. The sport management departments in universities have a greater role to manage this large economy efficiently. Many universities in Europe are updated sports management education programs according to these developments. But it can be said that the need for new reforms to Turkey's sports management education. Table 1 shows the sport management course curriculum (field courses) and course credits (ECTS) in Turkey.

Table 1 although important lessons about the value of field training courses are not taught by experts in the field of those lessons in Turkey

\section{Brand Value}

\begin{tabular}{l|l}
\hline Course Title & ECTS \\
\hline Introduction to Economics & 4 \\
\hline Sport Economics & 3 \\
\hline Sport Sponsorship & 4 \\
\hline Risk Management in Sport & 4 \\
\hline Event Management & 3 \\
\hline Sports Facility Management & 4 \\
\hline Sports Marketing & 4 \\
\hline Sport Finance & 4 \\
\hline
\end{tabular}

Brand value refers to the image in the mind of the consumers (Dinnie, 2015). The fans are the main consumers in the sports industry. The brand value of the European clubs has significantly improved over the past period of seven years. This is evident from the fact that loyal fans have significantly increased and shareholders increased their stake. Clubs playing in European top five leagues have been necessitated to expand their capacity so as to accommodate the increasing number of fans (Van Den Berg \& Braun, 2017). Previous researchers have only linked the improvements in the club's brand value to the increased support by the government, increased expertise by managers, and the increase in the number of loyal fans. There has been insufficient information on the impact of the UEFA financial fair play regulations on the brand value of the European clubs. UEFA financial fair play regulations have been focusing on the ability of the clubs to meet their long-term financial obligations. The brand value of the organization is depended on its ability to meet its financial obligations (Ramaswamy \& Ozcan, 2016). The fact that the UEFA financial fair play regulations have had a significant positive impact on the ability of the clubs to meet their long-term financial obligations due to the control directed on the spending implies that the regulations have also impacted on the clubs' brand value. Therefore, UEFA financial fair play regulations should also be listed as a factor behind the improvement in the brand value of the clubs in the past period of seven years since the regulations were implemented.

\section{Strategic Thinking}

Strategic thinking involves such activities as the analysis of the environment, establishment of the direction of the organization, formulation of the strategy, implementation of the strategy, and the control of the strategy (Betz, 2016). Effectiveness in strategic thinking brings about improvement in the decision-making process and hence rapid growth in the organization. Previous researchers on the reasons behind the rapid growth of the European clubs have been identifying improvement in strategic thinking as a result of the employment of managers with expertise in sports activities as a major factor. They have been providing insufficient information on the existing link between the UEFA fair play regulations and the strategic thinking and hence their combined impact on the economic growth and stability of the clubs. With the introduction of the UEFA financial fair play regulations, the decisions and strategies made by the European clubs have been based on the requirements.

The decisions and strategies made must comply with the financial requirements. The managers of the different clubs have been compelled by the UEFA financial fair play regulations to ensure that their strategies do not necessitate huge borrowings. Also, decisions that lead to overspending cannot be implemented as this can attract sanctions and disqualification of the clubs from taking part in the UEFA competitions (Ekstrand, et al., 2018). This limitation on the 
strategies and decisions has had a huge impact on the growth of the clubs. Therefore, through the improvement in the strategic thinking of the clubs' management, UEFA financial fair play has helped the clubs achieve higher success in their economic development goals and sustainability decisions. The ability to think strategically can be gained through cooperation with universities and various sports industry organizations.

\section{Sports Facilities}

In the sports management education curriculum, the management of sports facilities occupies an important place. Students receive theoretical training at university convert them into practice through internship and workplace experiences practices. Previous research shows that improvement in sports facilities has a huge impact on the economic growth of football clubs. Better facilities ensure that the players have had the best practices hence performing better in the matches (Halonen, et al., 2015). Previously, before the introduction of the UEFA financial fair play regulations, European clubs would overspend in the effort to acquire the best facilities and achieve improvement in their players' capability. This led to huge borrowing and huge debts which affected the trust of the fans, the confidence of the shareholders, and hence the economic growth and financial stability of the clubs. When the break-even assessments kicked off in the year 2011, the clubs would not spend more than they earn. This prevents huge spending on the facilities when the revenues of the company would not otherwise allow that. According to Guo and Liu (2017), the clubs' spending on the sports facilities is based on the revenue that they earn at the end of the season or financial year. This has prevented overspending and hence the increased financial stability of the clubs.

\section{Sponsorship}

The last relationship that scholars have not shed sufficient light is between sponsorship and the UEFA financial fair play regulations. Increased sponsorship leads to increased revenue and hence increased the economic growth of the clubs (Öztürk, 2015; Bakan \& Canöz, 2017; Sabrie, 2017; McDonald, 2014). This is a conclusion that most of the scholars have already agreed on. However, the impact of the UEFA regulations on the increased sponsors for the European clubs has not been sufficiently discussed. Sponsors go for the organizations with the best brand images. The brand images of the UEFA clubs have improved due to the introduction of the UEFA financial fair play regulations which prevent overspending. This has attracted many sponsors whose financial allocations have been used in the improvement of the different sports facilities and acquiring of the best talents in the industry. The end result of increased sponsors for the different clubs has been the increased growth of the clubs economically and increased financial stability.

\section{Findings}

It is clear from the above review of literature that scholars have not sufficiently described the impact that the UEFA financial fair play regulations have had on the economic growth and the financial stability of the European clubs. It is evident from the previous research that since the year 2011 when the assessments under the UEFA financial fair play began, European clubs, especially those which take part in the UEFA competitions, have had huge improvements. This is evidence of the fact that the UEFA regulations under the financial fair play have had a significant impact on the improvements achieved by the clubs. However, it has been observed that these developments should be adapted to the educational world, sports management education curricula should be reviewed and adapted to new developments.

The fact that the requirements have made it a mandatory for the clubs willing to take part in the UEFA competitions to have no bills has made managers ensure that their decisions and strategies do not lead the clubs into overspending. The clubs have been spending based on their revenues. This has had a huge impact on the financial stability of the clubs.

Also, the UEFA financial fair play regulations have had a huge impact on the brand value of the European clubs. The regulations have led to reduced cases of debts and hence increased the trust of the clubs by shareholders. This has led to an increase in investment which has been the greatest source of income for the clubs. The clubs have been using the high income to meet their financial obligations instead of borrowing hence achieving higher growth and high financial stability. The UEFA financial fair play regulations have also significantly affected the strategies and decisions made by the clubs. The decision-makers at the clubs must ensure that the strategies and decisions achieved do not require more spending than the revenue. Through their influence on the decisions and the strategies made, the regulations have helped ensure that the clubs have adopted the plans and initiatives that are within the budget. The UEFA requirements also prevent the clubs from spending more than they earn on the purchase of the sports facilities. Before their introduction, clubs would be tempted often to spend more on the facilities so as to have more capable players. This increased the spending and resulted in huge debts which were major factors behind the stagnant growth and the financial instability of the clubs. UEFA financial fair play regulations helped avoid overspending on the sports facilities and hence increased financial stability.

UEFA financial fair play regulation's impact on the brand value also significantly affected the sponsorship of the European clubs. The improved brand value of the clubs has attracted sponsors from around the world. Majority of the 
sponsors of the European clubs are global organizations. Examples include Fly Emirates, Yokohama, Chevrolet, Standard Chartered, Rakuten, and Etihad. These companies have huge financial capabilities. This makes them offer considerable amounts as sponsorship fee to the European clubs. High sponsorship fee has been a major factor behind the increased economic growth of the clubs and increased financial stability for the last period of seven years since UEFA diverted its major concern on the expenditure of the clubs.

\section{Results}

It is clear from the above review of literature that scholars have not sufficiently described the impact that the UEFA financial fair play regulations have had on the economic growth and the financial stability of the European clubs. It is evident from the previous research that since the year 2011 when the assessments under the UEFA financial fair play began, European clubs, especially those which take part in the UEFA competitions, have had huge improvements. This is evidence of the fact that the UEFA regulations under the financial fair play have had a significant impact on the improvements achieved by the clubs. However, it has been observed that these developments should be adapted to the educational world, sports management education curricula should be reviewed and adapted to new developments. The fact that the requirements have made it a mandatory for the clubs willing to take part in the UEFA competitions to have no bills has made managers ensure that their decisions and strategies do not lead the clubs into overspending. The clubs have been spending based on their revenues. This has had a huge impact on the financial stability of the clubs. Also, the UEFA financial fair play regulations have had a huge impact on the brand value of the European clubs. The regulations have led to reduced cases of debts and hence increased the trust of the clubs by shareholders. This has led to an increase in investment which has been the greatest source of income for the clubs. The clubs have been using the high income to meet their financial obligations instead of borrowing hence achieving higher growth and high financial stability. The UEFA financial fair play regulations have also significantly affected the strategies and decisions made by the clubs. The decision-makers at the clubs must ensure that the strategies and decisions achieved do not require more spending than the revenue. Through their influence on the decisions and the strategies made, the regulations have helped ensure that the clubs have adopted the plans and initiatives that are within the budget. The UEFA requirements also prevent the clubs from spending more than they earn on the purchase of the sports facilities. Before their introduction, clubs would be tempted often to spend more on the facilities so as to have more capable players. This increased the spending and resulted in huge debts which were major factors behind the stagnant growth and the financial instability of the clubs. UEFA financial fair play regulations helped avoid overspending on the sports facilities and hence increased financial stability. UEFA financial fair play regulation's impact on the brand value also significantly affected the sponsorship of the European clubs. The improved brand value of the clubs has attracted sponsors from around the world. Majority of the sponsors of the European clubs are global organizations. Examples include Fly Emirates, Yokohama, Chevrolet, Standard Chartered, Rakuten, and Etihad. These companies have huge financial capabilities. This makes them offer considerable amounts as sponsorship fee to the European clubs. High sponsorship fee has been a major factor behind the increased economic growth of the clubs and increased financial stability for the last period of seven years since UEFA diverted its major concern on the expenditure of the clubs. And, finally, the sports management departments at universities should make curriculum updates in line with the needs of the sports economy. The courses in the sports management curriculum should also be given by field experts.

\section{Discussion}

It is clear that UEFA financial fair play has had a huge impact on the growth of the European clubs and their financial stability. This has been mainly achieved due to the influence of the regulations on the spending pattern of the clubs. Since the implementation of the regulations, the clubs have been spending based on their revenue. This has resulted in reduced cases of debts and increased savings and investment by the clubs in different businesses. Due to the regulations, the issue of debts has coexisted among many of the European clubs. This has led to increased trust among the shareholders and hence increased investment. Also, lack of huge debts among the clubs has increased their brand value. The higher brand value had encouraged global companies to sponsor the clubs. The revenue obtained from the huge investments and sponsorship fee has been used in the development projects, acquiring new sports facilities, and acquiring the services of the best talents in the industry. This has resulted in a significant growth in the economy of the clubs and the increased stability of the clubs in terms of finance. The only area in which the fair play has failed is on the clubs to be subjected to the break-even assessments. The clubs that have qualified to take part in the UEFA competitions and those willing are the only ones which are subjected to the assessments and which are required to comply with the fair play requirements. This has led to increased economic growth and increased financial stability of the big clubs in the continent. Small clubs playing in second, third, and other lower leagues are not subjected to these assessments. They still remain undeveloped due to huge debts and financial instabilities. The fair play regulations should be extended to all the football clubs in Europe so as to give them the opportunity to grow and become competitive at the top leagues. More research should be done on the ways in which the UEFA financial fair play regulations should be improved so as to increase the growth and the financial 
stability of the football clubs in the European continent. The education of the managers who will be preferred in the management of football clubs should be updated according to the needs of the football industry. The demand of the professional and talented sports manager of the football industry is increasing. The education world should be prepared for this increase. Further studies are needed to enable students to acquire skills such as foreign language learning, financial literacy and social communication.

\section{References}

Alleyne, M., Alleyne, P., \& Greenidge, D. (2010). Life Satisfaction and Perceived Stress among UniversityStudents in Barbados. Journal of Psychology in Africa, 20(2), 291-298. https://doi.org/10.1080/14330237.2010.10820378

Appendini, K., \& Bislev, S. (Eds.). (2016). Economic integration in NAFTA and the EU: Deficient institutionally. Springer, London.

Bakan, Ö., \& Canöz, N. (2017). Presentation of Sponsorship Activities on the Web Sites of Airline Companies: Turkish Airlines Case. Communication and Digital Media, 33-40.

Caglio, A., D'Andrea, A., Masciandaro, D., \& Ottaviano, G. I. P. (2016). Does Fair Play Matter? UEFA Regulation and Financial Sustainability in the European Football Industry (October 1, 2016). Baffi Carefin Centre Research Paper No. 2016-38. https://doi.org/10.2139/ssrn.2853349

Caz, Ç., \& Tunçkol, H. M. (2015). Beden eğitimi öğretmenlerinin zaman yönetimi becerilerinin incelenmesi. Spor ve Performans Araştırmaları Dergisi, 6(2), 91-100. https://doi.org/10.17155/spd.18730

Demir, A., \& Akın, M. (2018). Aktif Video Oyunları ve Wobble Board Denge Antrenmanının 6 Yaş Çocuklarda Dinamik Dengeye Etkisinin Karşılaştırılması. Gaziantep Üniversitesi Spor Bilimleri Dergisi, 3(4), 109-121. https://doi.org/10.31680/gaunjss.461858

Dinnie, K. (2015). Nation Branding: Concepts, issues, practice. Routledge.

Ekstrand, J., Lundqvist, D., Davison, M., D’Hooghe, M., \& Pensgaard, A. M. (2019). Communication quality between the medical team and the head coach/manager is associated with injury burden and player availability in elite football clubs. Br J Sports Med, 53, 304-308. https://doi.org/10.1136/bjsports-2018-099411

Fernandes, J. P. (2016). The impact of UEFA's Club Licensing \& Financial Fair Play regulations and their compatibility with EU law (Unpublished master's thesis), Universidade do Minho Escola de Direito, Braga

Franck, E. P. (2014). Financial Fair Play in European Club Football What is it all about? Working Papers 328, University of Zurich, Department of Business Administration (IBW). https://doi.org/10.2139/ssrn.2284615

Galariotis, E., Germain, C., \& Zopounidis, C. (2018). A combined methodology for the concurrent evaluation of the business, financial and sports performance of football clubs: the case of France. Annals of Operations Research, 266(1-2), 589-612. https://doi.org/10.1007/s10479-017-2631-z

Geurts, J. S. (2016). Football players' transfer price determination based on performance in the Big 5 European leagues (Unpublished master's thesis), School of Business and Economics, Universidate Nova de Lisboa.

Gomes, M., Conceição, C. S., de Lima Brasileiro, A. J. A., de Sousa, C. S., Carvalho, V. O., \& de Jesus, F. L. A. (2017). Effects of the FIFA 11 training program on injury prevention and performance in football players: a systematic review and meta-analysis. Clinical Rehabilitation, 31(5), 651-659. https://doi.org/10.1177/0269215516675906

Halonen, J. I., Stenholm, S., Kivimäki, M., Pentti, J., Subramanian, S. V., Kawachi, I., \& Vahtera, J. (2015). Is change in availability of sports facilities associated with change in physical activity? A prospective cohort study. Preventive medicine, 73, 10-14. https://doi.org/10.1016/j.ypmed.2015.01.012

Houlihan, B., \& Malcolm, D. (Eds.). (2015). Sport and society: a student introduction. Sage, California

Kuper, S. (2014). Soccernomics: Why England Loses, Why Spain, Germany, and Brazil Win, and Why the US, Japan, Australia, and Even Iraq Are Destined to Become the Kings of the World's Most Popular Sport. Nation Books, NewYork

Leeds, M. A., Von Allmen, P., \& Matheson, V. A. (2018). The economics of sports. Routledge, London. https://doi.org/10.4324/9781315167947

Lewis, A., \& Taylor, J. (2014). Sport: law and practice. Bloomsbury Professional, West Sussex

Matthew, B. T. (2017). Financial management in the sports industry. Routledge, London. https://doi.org/10.4324/9781315213064

McDonald, M. (2014). How regimes dictate oligarchs \& their football clubs: Case studies comparison of Oligarch 
Football Club ownership in Dagestan, Romania, \& Transnistria from 1990-2014 (Unpublished master's thesis), Russian and East European Studies in the Graduate School, The University of North Carolina at Chapel Hill, USA

McLeod, H. (2016). Religion, Politics and Sport in Western Europe, c.1870-1939', in Stewart J. Brown, Frances Knight, and John Morgan-Guy(Eds), Religion, Identity and Conflict in Britain (Farnham: Ashgate, 2013), 195-212.

Mellström, U. (2017). Masculinity, power, and technology: A Malaysian ethnography. Routledge. https://doi.org/10.4324/9781315249537

Mumcu, H. E., Acet, M., Kusan, O., Zambak, Ö, \& Koç, M. C. (2017). Examining to see elite sight-disabled athletes according to the dimensions of the scale of motivation in sport. Journal of Human Sciences, 14(3), 2590-2600. https://doi.org/10.14687/jhs.v14i3.4395

Nicoliello, M., \& Zampatti, D. (2016). Football clubs' profitability after the Financial Fair Play regulation: evidence from Italy. Sport, Business and Management: An International Journal, 6(4), 460-475. https://doi.org/10.1108/SBM-07-2014-0037

Özbay, S., Ulupınar, S., \& Özkara, A. B. (2018). Sporda Çeviklik Performansı. Ulusal Spor Bilimleri Dergisi, 2(2), 97-112. https://doi.org/10.30769/usbd.463364

Özkara, A. B. (2018). Physical education in EU schools and Turkey: A comparative study. Comparative Professional Pedagogy 8(2), 101-106. https://doi.org/10.2478/rpp-2018-0026

Özkara, A. B., Kalkavan, A., Alemdağ, S., Alemdağ, C., \& Çavdar, S. (2017). The role of physical activity in pre-service teachers' subjective vitality. Physical education of students, 21(3), 134-139. https://doi.org/10.15561/20755279.2017.0306

Öztürk, H. (2015). Financial fair play regulations and the future of European football. International Sports Law Review Pandektis, 11(1-2), 584-617.

Preuss, H., Haugen, K., \& Schubert, M. (2014). UEFA financial fair play: the curse of regulation. European Journal of Sports Studies, 2(1), 33-51.

Ramaswamy, V., \& Ozcan, K. (2016). Brand value co-creation in a digitalized world: An integrative framework and research implications. International Journal of Research in Marketing, 33(1), 93-106. https://doi.org/10.1016/j.ijresmar.2015.07.001

Sabrie, B. A. (2017). Revenue Generation and Its Effect on the Profitability of Football Clubs (Unpublished master's thesis), Chandaria School of Business, United States International University Africa, Nairobi City, Kenya

Sass, M. (2016). Glory hunters, sugar daddies, and long-term competitive balance under UEFA Financial Fair Play. Journal of Sports Economics, 17(2), 148-158. https://doi.org/10.1177/1527002514526412

Schubert, M., Könecke, T., \& Pitthan, H. (2016). The guardians of European football: UEFA Financial Fair Play and the career of social problems. European Journal for Sport and Society, 13(4), 296-324. https://doi.org/10.1080/16138171.2016.1248094

Togo, O. T., Caz, C., \& Kayhan, R. F. (2018). The relationship between resilience and constant hope in students studying sports science. European Journal of Educational Research, 6(4), 583-589.

Toktas \& Bas (2019). Investigation of the relationship between the self-confidence and motivation of high school students participating school sport contests.Universal Journal of Educational Research, 7, 472-479. https://doi.org/10.13189/ujer.2019.070220

Van Den Berg, L., \& Braun, E. (2017). Sports and city marketing in European cities. Routledge, London. https://doi.org/10.4324/9781315242576

Yllmaz, A. (2018). Parent expectations towards participation to extracurricular sport activity of high school students. Pedagogics, Psychology, Medical-Biological Problems of Physical Training and Sports, 22(4), 216-225. https://doi.org/10.15561/18189172.2018.0408

\section{Copyrights}

Copyright for this article is retained by the author(s), with first publication rights granted to the journal.

This is an open-access article distributed under the terms and conditions of the Creative Commons Attribution license which permits unrestricted use, distribution, and reproduction in any medium, provided the original work is properly cited. 